\title{
Short communication: Environmental mastitis pathogen counts in freestalls bedded with composted and fresh recycled manure solids
}

\author{
K. J. Cole and J. S. Hogan ${ }^{1}$ \\ Ohio Agricultural Research and Development Center, The Ohio State University, Wooster 44691
}

\section{ABSTRACT}

An experiment was conducted to compare bacterial counts of environmental mastitis pathogens in composted recycled manure solids bedding with those in fresh recycled manure solids. Eighteen Holstein cows were housed in 1 pen with 18 stalls. One row of 9 freestalls included mattresses and was bedded weekly with composted recycled manure solids. The second row of 9 freestalls included mattresses and was bedded weekly with fresh recycled manure solids. The back one-third of stalls toward the alleyway was covered in 25 to 50 $\mathrm{mm}$ of bedding. Samples were taken from the back onethird of 4 stalls for both treatments on d 0, 1, 2, and 6 of each week. After $3 \mathrm{wk}$, bedding treatments were switched between rows, making the total duration 6 wk. Mean total gram-negative bacterial counts were approximately $0.5 \log _{10} \mathrm{cfu} / \mathrm{g}$ of dry matter lower in the composted recycled manure solids on d 0 compared with fresh recycled manure solids. Klebsiella species, coliform, and Streptococcus species counts were at least $1.0 \log _{10} \mathrm{cfu} / \mathrm{g}$ of dry matter lower in composted compared with fresh recycled manure solids on d 0. Only gram-negative bacterial counts on d 1 were reduced in composted recycled manure solids compared with fresh recycled manure solids. Differences were not observed between treatments in gram-negative bacterial, coliform, Klebsiella species, or Streptococcus species counts on d 2 and 6. Ash content was higher in composted recycled manure solids compared with fresh recycled manure solids on d 0, 1, 2, and 6. Despite the increase in ash after composting, bacterial counts of mastitis pathogens in composted recycled manure solids were comparable with those in fresh recycled manure when used as freestall bedding.

Key words: recycled manure solids, compost, bacterial count

Received August 10, 2015.

Accepted October 26, 2015

${ }^{1}$ Corresponding author: hogan.4@osu.edu

\section{Short Communication}

Recycled manure solids (RMS) used as bedding are prepared by separation of the solids from the liquids of cow manure (Carroll and Jasper, 1978). Unused RMS initially have low bacterial counts of environmental mastitis pathogens, but counts rise exponentially within a few hours after being exposed to the cows and introducing bacterial contamination (Sorter et al., 2014). Composting can be a beneficial method in decreasing bacterial load in organic materials such as RMS (Carroll and Jasper, 1978). Composting is the process of breaking down organic material by bacteria, which helps decrease the populations of potential pathogens in materials coming in contact with plants and animals (NRAES, 1992). Compost piles can reach thermophilic temperatures of 50 to $60^{\circ} \mathrm{C}$, with temperatures upwards of $55^{\circ} \mathrm{C}$ inhibiting coliforms and other bacteria commonly associated with bovine mastitis (Keener, 2011). Studies on the effects of composting bedding for dairy cows have compared composted RMS and fresh RMS by survey of different farms (Husfeldt et al., 2012). Reports are limited comparing fresh RMS and composted RMS under similar environmental conditions using the same cows within one farm. The purpose of the current study was to investigate if composted RMS decreases bacterial counts of mastitis pathogens compared with fresh RMS used as freestall bedding for dairy cows.

A 6-wk research trial was conducted July 8 to August 18, 2014, at the Krauss Dairy, Ohio Agricultural Research and Development Center, Wooster, Ohio. This experiment took place in an 18-freestall pen, housing 18 multiparous mid- to late-lactation Holstein cows. Each stall consisted of a concrete base $203 \times 127 \mathrm{~cm}$ with rubber filled, vinyl-surfaced, cushioned mats. The pen consisted of 2 rows of 9 freestalls separated toward the back of stalls by a $3.05-\mathrm{m}$ alleyway. Fans (1.2 m diagonal propeller length) were placed in the barn every 6.1 $\mathrm{m}$ and suspended $2.7 \mathrm{~m}$ above both rows of freestalls. Stalls were separated from feed and water by a $2.13-\mathrm{m}-$ wide alley and a solid wall $1.22 \mathrm{~m}$ in height. Stalls were separated from the exterior side-open walls of the barn by 1.22-m-high wall and a 1.5-m transport alley (Sorter 
et al., 2014). The pen and feed alleys were cleaned by manual scrapers that ran 8 cycles every $24 \mathrm{~h}$. Climatological data were recorded at the Ohio Agricultural Research and Development Weather Station $1.7 \mathrm{~km}$ from the Krauss Dairy and $1.4 \mathrm{~km}$ from the compost pad. During the experimental days of July 8 to August 18, 2014, average daily temperature ranged from 15.8 to $25.6^{\circ} \mathrm{C}$ and average daily relative humidity ranged from 23.3 to $35 \%$.

All RMS used in the trial were the result of manure collected from alleyways of freestalls and tie-stalls housing lactating cows at the Krauss Dairy. Manure was scraped into a central liquid retention pit and pumped through an extractor (FAN PSS, Fan Separator Inc., Michigan City, IN) to separate the solids from the liquids. The fresh RMS were solids from the separator stored under a covered shed for $48 \mathrm{~h}$ before use as bedding in the trial. Composted RMS were produced from 2 rows of 25 to $30 \mathrm{~m}^{3}$ of the fresh RMS composted sequentially for 4 wk each on a $2,023 \mathrm{~m}^{2}$, uncovered, concrete composting pad with a $2 \%$ slope and a leachate collection system. The dimensions of windrows were approximately $23 \mathrm{~m}$ long, $3 \mathrm{~m}$ wide, and $1 \mathrm{~m}$ high. Windrows were turned weekly with a tractorassisted Aeromaster 120 windrow turner (Midwest Bio-Systems, Tampico, IL; Michel et al., 2004). Four equidistant, representative samples of RMS were taken from the windrows before the composting periods and at the completion of composting periods to monitor bacteriological counts and DM. Windrow 1 was on the pad from June 2 to July 7, 2014 (total rainfall $16 \mathrm{~cm}$, average daily temperature ranged from 15.9 to $27.3^{\circ} \mathrm{C}$, and average daily humidity ranged from 18.8 to $32.8 \%$ ). Windrow 2 was on the pad from June 23 to July 28, 2014 (total rainfall $11.15 \mathrm{~cm}$, average daily temperature ranged from 16.3 to $27.8^{\circ} \mathrm{C}$, and average daily humidity ranged from 22.2 to $34.5 \%$ ).

Both rows of 9 freestalls were bedded with $30 \mathrm{~kg}$ of RMS per stall weekly. The back one-third of stalls toward the alleyway in one row was bedded to a depth of 25 to $50 \mathrm{~mm}$ of composted RMS. The back onethird of stalls toward the alleyway of the other row was bedded to a depth of 25 to $50 \mathrm{~mm}$ of fresh RMS. Bedding treatments remained in their assigned rows for 3 consecutive weeks. After the first $3 \mathrm{wk}$, the treatments were switched between rows. The trial lasted 6 wk, allowing both rows to be exposed to the treatments for 3 wk each.

Bedding samples from 4 stalls per treatment group were collected from the surface $25 \mathrm{~mm}$ of bedding in the back one-third of stalls. Stalls located directly across the walk alley between rows (tail to tail) were paired for statistical analysis. Stalls selected were the second, fourth, sixth, and eighth stall in the sequence of the
9 stall rows. Each sample from each stall consisted of 3 equidistant subsamples that were combined to form one sample weighing approximately 200 g. Samples were collected at the same time each week from both experimental groups immediately after fresh bedding was added to stalls (d 0) and on d 1, 2, and 6 after use as bedding. The samples were tested for DM, ash, and bacteriological counts.

Dry matter was determined by placing $2 \mathrm{~g}$ of sample in $5.7 \times 1.6 \mathrm{~cm}$ aluminum pans. The samples were weighed for wet weight and then placed in a gravityconvection oven at $100^{\circ} \mathrm{C}$ for $24 \mathrm{~h}$. The samples were removed from the oven and re-weighed to determine the DM content. Ash was determined by placing $2 \mathrm{~g}$ from each sample, in a $43 \times 37 \mathrm{~mm}$ high form porcelain crucible (VWR International, Radnor, PA), in a gravity convection oven at $100^{\circ} \mathrm{C}$ for $24 \mathrm{~h}$. Following DM determination, crucibles containing dried bedding were then placed in an oven and heated to $600^{\circ} \mathrm{C}$ for at least $12 \mathrm{~h}$ to determine ash. Bacteriological counts were determined by serial dilution of samples in PBS using the procedures and materials detailed by Sorter et al. (2014).

Differences in bacterial counts and DM in RMS windrows before composting and after composting were compared using Student's t-test. Data analysis for bacterial counts, DM, and ash content in freestall samples consisted of multivariate ANOVA. Factors included in the model were treatment, pair (i.e., location), sample day, period, and week (nested within period). The analysis included main effects and possible sample day $\times$ treatment interactions. Analysis was performed using the GLM and GLIMMIX procedures in SAS version 9.4 (SAS Institute Inc., Cary, NC). Significance level was set at $P<0.05$ for main effects. To adjust for multiple comparisons within each model, Tukey's adjusted $P$-values $(P<0.05$ for each pair-wise difference) were calculated for each variable.

Gram-negative bacteria, coliform, and streptococcal counts in RMS windrows were reduced $(P<0.05)$ after 4 wk composting compared with counts in windrows before composting (Table 1). Klebsiella counts and DM did not differ $(P>0.05)$ in samples taken from windrows before composting and samples taken from the windrows after 4 wk of composting RMS.

Composting RMS reduced bacterial counts before use as bedding, but had little effect on bacterial counts after use as bedding in freestalls. Gram-negative bacterial, coliform, Klebsiella species, and Streptococcus species counts were each reduced $(P<0.05)$ in the composted RMS compared with fresh RMS at the time bedding was placed in the freestalls on d 0 (Table 2). Gram-negative bacterial counts were the only counts reduced $(P<0.05)$ in composted RMS compared with 
Table 1. Gram-negative bacterial, coliform, Klebsiella spp., and Streptococcus spp. counts (cfu $\log _{10} / \mathrm{g}$ of DM) and DM for recycled manure solids before and after 4 wk composting $(n=4)$

\begin{tabular}{llcc}
\hline & & \multicolumn{2}{c}{ Composting } \\
\cline { 3 - 4 } Variable & & Prior & After \\
\hline Gram-negative & Mean & $7.62^{\mathrm{a}}$ & $5.13^{\mathrm{b}}$ \\
& SE & 0.14 & 0.30 \\
Coliform & Mean & $3.81^{\mathrm{a}}$ & $3.16^{\mathrm{b}}$ \\
& SE & 0.17 & 0.20 \\
Klebsiella spp. & Mean & 3.12 & 3.04 \\
Streptococcus spp. & SE & 0.18 & 0.09 \\
& Mean & $4.31^{\mathrm{a}}$ & $3.39^{\mathrm{b}}$ \\
DM (\%) & SE & 0.28 & 0.33 \\
& Mean & 27.62 & 27.90 \\
& SE & 0.02 & 0.01 \\
\hline
\end{tabular}

$\overline{\mathrm{a}, \mathrm{b}}$ Means within variable differ between prior and after composting $(P$ $<0.05)$.

fresh RMS on d 1. Gram-negative bacterial counts did not differ $(P>0.05)$ between composted RMS and fresh RMS on d 2 and 6. Coliform, Klebsiella species, and Streptococcus species counts did not differ between composted and fresh RMS on d 1,2, and 6 after use as bedding. Therefore, composting RMS offered minimal advantages over fresh RMS in reducing bacterial counts of common mastitis pathogens in bedding for dairy cows in freestalls.
Bacterial counts in both composted and fresh RMS increased rapidly from d 0 to 1 and remained relatively constant on d 1, 2, and 6. Gram-negative bacterial, coliform, Klebsiella species, and Streptococcus species counts in both composted and fresh RMS were each lower $(P<0.05)$ on $\mathrm{d} 0$ than on $\mathrm{d} 1,2$, and 6 (Table $2)$. Gram-negative bacterial counts did not differ $(P>$ $0.05)$ between $\mathrm{d} 1$ and 2 within treatments, but were lower $(P<0.05)$ on $\mathrm{d} 6$ than on $\mathrm{d} 1$ and 2 within both fresh and composted RMS. Klebsiella species counts did not differ $(P>0.05)$ among $d 1,2$, and 6 in composted RMS. In fresh RMS, Klebsiella species counts were lower $(P<0.05)$ on $\mathrm{d} 1$ than d 2 , but d 1 and 6 counts did not differ $(P>0.05)$. Coliform and Streptococcus species counts did not differ $(P>0.05)$ among d 1,2 , and 6 within treatments.

The initial reduction of bacterial counts after composting RMS and the rapid increase in counts after use as bedding is consistent with previous reports. In vitro studies investigating growth of environmental bacteria in RMS bedding materials under controlled conditions and independent of the presence of feces, urine, and other contamination also reported rapid increases in bacterial counts in the first $24 \mathrm{~h}$ after inoculation. Bacterial populations entered stationary growth phase by d 1 after inoculation into RMS (Zehner et al., 1986; God-

Table 2. Gram-negative bacterial, coliform, Klebsiella spp., and Streptococcus spp. counts (cfu $\log _{10} / \mathrm{g}$ of DM), $\mathrm{DM}$, and ash by day of sampling for composted and fresh recycled manure solids $(\mathrm{n}=24)$

\begin{tabular}{|c|c|c|c|c|c|c|}
\hline \multirow[b]{2}{*}{ Variable } & \multirow[b]{2}{*}{ Treatment } & & \multicolumn{4}{|c|}{ Days } \\
\hline & & & 0 & 1 & 2 & 6 \\
\hline \multirow[t]{4}{*}{ Gram-negative } & Compost & Mean & $6.45^{\mathrm{a}, \mathrm{d}}$ & $8.21^{\mathrm{b}, \mathrm{d}}$ & $8.35^{\mathrm{b}}$ & $7.66^{\mathrm{c}}$ \\
\hline & & $\mathrm{SE}$ & 0.11 & 0.06 & 0.08 & 0.07 \\
\hline & Fresh & Mean & $6.92^{\mathrm{a}, \mathrm{e}}$ & $8.77^{\mathrm{b}, \mathrm{e}}$ & $8.65^{\mathrm{b}}$ & $7.87^{\mathrm{c}}$ \\
\hline & & SE & 0.10 & 0.03 & 0.05 & 0.08 \\
\hline \multirow[t]{4}{*}{ Coliform } & Compost & Mean & $3.34^{\mathrm{a}, \mathrm{d}}$ & $7.12^{\mathrm{b}}$ & $7.09^{\mathrm{b}}$ & $7.02^{\mathrm{b}}$ \\
\hline & & $\mathrm{SE}$ & 0.14 & 0.09 & 0.07 & 0.05 \\
\hline & Fresh & Mean & $5.25^{\mathrm{a}, \mathrm{e}}$ & $7.07^{\mathrm{b}}$ & $7.24^{\mathrm{b}}$ & $7.23^{\mathrm{b}}$ \\
\hline & & $\mathrm{SE}$ & 0.26 & 0.11 & 0.11 & 0.10 \\
\hline \multirow[t]{4}{*}{ Klebsiella spp. } & Compost & Mean & $3.04^{\mathrm{a}, \mathrm{d}}$ & $5.03^{\mathrm{b}}$ & $5.48^{\mathrm{b}}$ & $5.36^{\mathrm{b}}$ \\
\hline & & $\mathrm{SE}$ & 0.06 & 0.17 & 0.15 & 0.12 \\
\hline & Fresh & Mean & $4.07^{\mathrm{a}, \mathrm{e}}$ & $5.41^{\mathrm{b}}$ & $6.04^{\mathrm{c}}$ & $5.90^{\mathrm{bc}}$ \\
\hline & & $\mathrm{SE}$ & 0.17 & 0.17 & 0.14 & 0.14 \\
\hline \multirow{4}{*}{ Streptococcus spp. } & Compost & Mean & $4.75^{\mathrm{a}, \mathrm{d}}$ & $8.46^{\mathrm{b}}$ & $8.68^{b}$ & $8.84^{\mathrm{b}}$ \\
\hline & & $\mathrm{SE}$ & 0.17 & 0.10 & 0.09 & 0.06 \\
\hline & Fresh & Mean & $6.57^{\text {ae }}$ & $8.38^{\mathrm{b}}$ & $8.58^{\mathrm{b}}$ & $8.60^{\mathrm{b}}$ \\
\hline & & $\mathrm{SE}$ & 0.25 & 0.08 & 0.08 & 0.08 \\
\hline \multirow[t]{4}{*}{$\mathrm{DM}(\%)$} & Compost & Mean & $27.5^{\mathrm{a}}$ & $32.2^{\mathrm{b}, \mathrm{d}}$ & $35.9^{\text {bd }}$ & $54.1^{\mathrm{c}}$ \\
\hline & & $\mathrm{SE}$ & 0.2 & 0.5 & 0.5 & 1.9 \\
\hline & Fresh & Mean & $31.5^{\mathrm{a}}$ & $36.8^{\mathrm{b}, \mathrm{e}}$ & $41.3^{\mathrm{b}, \mathrm{e}}$ & $54.5^{\mathrm{c}}$ \\
\hline & & $\mathrm{SE}$ & 0.4 & 0.6 & 0.6 & 1.7 \\
\hline \multirow{4}{*}{ Ash (\%) } & Compost & Mean & $9.3^{\mathrm{d}}$ & $9.1^{\mathrm{d}}$ & $9.9^{\mathrm{d}}$ & $9.9^{\mathrm{d}}$ \\
\hline & & SE & 0.3 & 0.2 & 0.2 & 0.2 \\
\hline & Fresh & Mean & $5.3^{\mathrm{a}, \mathrm{e}}$ & $6.1^{\mathrm{ab}, \mathrm{e}}$ & $6.4^{\mathrm{b}, \mathrm{e}}$ & $6.7^{\mathrm{b}, \mathrm{e}}$ \\
\hline & & SE & 0.2 & 0.2 & 0.2 & 0.2 \\
\hline
\end{tabular}

${ }^{\mathrm{a}-\mathrm{c}}$ Means within treatment differ among sample days $(P<0.05)$.

d,e Means within day differ between treatments $(P<0.05)$. 
den et al., 2008). Carroll and Jasper (1978) reported that composting RMS effectively reduced coliform counts in compost piles. However, given the proper growth conditions of moisture and temperature when used as bedding in stalls, coliforms increased rapidly to large numbers in composted RMS due to replication of either bacteria surviving composting or those from external contamination (Carroll and Jasper, 1978). An important source of contamination for bedding in freestalls is manure on hooves and legs of cows that inoculate bedding material with fecal matter containing organisms. Environmental mastitis pathogens such as coliforms and environmental streptococci are shed in a significant amount by cows in their feces every day. These pathogens are normal inhabitants of the digestive tract and are excreted through the manure. In the current study, the design of the experiment provided a common walk alley between experimental stalls; thus, manure from the alley taken into the stalls on cow legs and hooves was from a common source of contamination to both composted and fresh RMS. This may explain the similar bacterial counts between bedding treatments in the current study as the primary source of bacteria to contaminate, and subsequently replicate, in bedding would be the fecal bacteria derived from manure in the common use alley for both treatments. Therefore, while composting initially reduced bacterial counts in the windrows, composted RMS appeared to have minimal advantage over fresh RMS on reducing bacterial growth of environmental mastitis pathogens when used as bedding under similar housing and environmental conditions.

Overall, the composting process did alter the physical characteristics of manure as previously reported (Eghball et al., 1997). Ash content of RMS differed between treatments and among days $(P<0.05)$. Ash content in composted RMS was greater $(P<0.05)$ compared with fresh RMS on d $0,1,2$, and 6 (Table 2 ). Within composted RMS, ash content did not differ $(P>0.05)$ among d 0, 1, 2, and 6. Ash content in fresh RMS did not differ $(P>0.05)$ between $\mathrm{d} 0$ and 1 , but $\mathrm{d} 0$ was lower $(P<0.05)$ than $\mathrm{d} 2$ and 6 . Ash content did not differ $(P>0.05)$ among $\mathrm{d} 1,2$, and 6 in fresh RMS. Composting decreases bacterial counts by heating the environment in piles or windrows to temperatures beyond survival range for most bacteria, and potentially altering the physical and chemical composition of the organic material. Carroll and Jasper (1978) and Mote et al. (1988) indicated that an increase in temperature into the thermophilic range decreased bacterial counts and OM. The reduction in OM was speculated to reduce subsequent growth by pathogens due to the reduction in available organic materials available for chemotrophic metabolism (Eghball et al., 1997). In the current study, composted RMS had reduced bacterial counts and increased ash content before use as bedding. Although the ash content of RMS was increased in composted RMS compared with fresh RMS before use and during use as bedding, this change in bedding composition did not result in an inhibition of common environmental mastitis pathogens.

Composted RMS DM on d 1 and 2 were lower $(P<$ 0.05) compared with fresh RMS on d 1 and 2 (Table $2)$. Composted RMS and fresh RMS did not differ $(P>$ $0.05)$ in DM on d 0 or 6 . Dry matter on d 0 was lower $(P<0.05)$ compared with d 1,2 , and 6 within both composted and fresh RMS. Dry matter content on $\mathrm{d}$ 1 and 2 were reduced $(P<0.05)$ in both composted and fresh RMS compared with d 6. Dry matter did not differ $(P>0.05)$ between d 1 and 2 within either treatment. An increase in DM over time with use of RMS as bedding was also seen by Husfeldt et al. (2012) and Sorter et al. (2014).

The results of the current study indicating composted RMS only had an effect on bacterial counts before use as bedding were similar to those comparing fresh RMS untreated or treated with disinfectants before use as bedding (Hogan et al., 1999, 2007). The use of disinfectants initially reduced bacterial counts, but antibacterial effects had diminished by d 2 after application (Hogan et al., 1999, 2007). In general, the counts of each bacterial group measured in the current and previous studies (Hogan et al., 1999, 2007) reached stationary phase by d 1 after use in both composted and fresh RMS, and counts persisted until bedding was changed weekly. Regardless of the management strategies tested in attempt to reduce bacterial counts in RMS bedding, bacterial counts of common environmental pathogens in freestalls increased rapidly once RMS is used as bedding and counts remained elevated throughout the current and previous (Hogan et al., 1999, 2007) trials.

\section{ACKNOWLEDGMENTS}

Salaries and research support were provided by state and federal funds appropriated to the Ohio Agricultural Research and Development Center, The Ohio State University, Hatch Project 390.

\section{REFERENCES}

Carroll, E. J., and D. E. Jasper. 1978. Distribution of Enterobacteriaceae in recycled manure bedding on California dairies. J. Dairy Sci. 61:1498-1508.

Eghball, B., J. F. Power, J. E. Gilley, and J. W. Doran. 1997. Waste management: Nutrient, carbon, and mass loss during composting of beef cattle feedlot manure. J. Environ. Qual. 26:189-193.

Godden, S., R. Bey, K. Lorch, R. Farnsworth, and P. Rapnicki. 2008. Ability of organic and inorganic bedding materials to promote growth of environmental bacteria. J. Dairy Sci. 91:151-159. 
Hogan, J. S., V. L. Bogacz, L. M. Thompson, S. Romig, P. S. Schoenberger, W. P. Weiss, and K. L. Smith. 1999. Bacterial counts associated with sawdust and recycled manure bedding treated with commercial conditioners. J. Dairy Sci. 82:1690-1695.

Hogan, J. S., S. L. Wolf, and C. S. Petersson-Wolfe. 2007. Bacterial counts in organic materials used as freestall bedding following treatment with a commercial conditioner. J. Dairy Sci. 90:1058 1062 .

Husfeldt, A. W., M. I. Endres, J. A. Salfer, and K. A. Janni. 2012 Management and characteristics of recycled manure solids used for bedding in Midwest freestall dairy herds. J. Dairy Sci. 95:21952203.

Keener, H. M. 2011. Challenges and Opportunities in Composting Organic Waste, Chapter 18. Climate Change and Food Security in South Asia. Pages 295-324 in Proc. Int. Symp. on Organics Recycling (ISOR). Springer Science Publishing, New York, NY.
Michel, F. C., J. A. Pecchia, J. Rigot, and H. M. Keener. 2004. Mass and nutrient losses during the composting of dairy manure amended with sawdust or straw. Compost Sci. Util. 12:323-334.

Mote, C. R., B. L. Emerton, J. S. Allison, H. H. Dowlen, and S. P. Oliver. 1988. Survival of coliform bacteria in static compost piles of dairy waste solids intended for freestall bedding. J. Dairy Sci. 71:1676-1681.

NRAES. 1992. On-Farm Composting Handbook. R. Rynk, ed. NRAES-54. Northeast Regional Agricultural Engineering Service, Ithaca, NY.

Sorter, D. E., H. J. Kester, and J. S. Hogan. 2014. Bacterial counts in recycled manure solids bedding replaced daily or deep packed in freestalls. J. Dairy Sci. 97:2965-2968.

Zehner, M. M., R. J. Farnsworth, R. D. Appleman, K. Larntz, and J. A. Springer. 1986. Growth of environmental mastitis pathogens in various bedding materials. J. Dairy Sci. 69:1932-1941. 